UDC 543.4

Assaf H. Tawfeeq, Bushra B. Qassim

\title{
A GREEN METHOD FOR ASSAY OF DOXYCYCLINE HYCLATE USING CONTINUOUS FLOW INJECTION/MERGING ZONES TECHNIQUE VIA COUPLING WITH AZO METOL IN AQUEOUS MEDIUM
}

\author{
University of Baghdad, Baghdad, Iraq
}

\begin{abstract}
A simple, automated, sensitive and environmentally friendly flow-injection/merging zones technique was developed for the determination of doxycycline hyclate in raw materials and pharmaceutical formulations. This method involves the reaction of azo metol with doxycycline hyclate to produce a yellow dissolved complex with a $\lambda_{\max }=445 \mathrm{~nm}$. The developed technique is simply and low-cost, it provides the use of an aqueous medium that is nontoxic and causes no pollution, thereby belonging to green chemistry. The method is sensitive, precise and accurate; the limit of detection is less than $0.3 \mu \mathrm{g} \mathrm{mL} \mathrm{L}^{-1}$, the relative standard deviation is less than $1.5 \%$ and the recovery is about $98 \%$. Various chemical and physical conditions that affected the reaction have been studied. An analytical calibration curve was linear within the concentration range of 5 to $125 \mu \mathrm{g} \mathrm{mL}{ }^{-1}$. The sample throughput is about 120 samples per hour. The proposed procedure can be successfully applied to estimate the content of doxycycline hyclate. The results of determination are satisfactory as compared with those given by a reference method of British Pharmacopeia: there is no significant difference between the results obtained by both methods regarding accuracy and precision at the $95 \%$ confidence level.
\end{abstract}

Keyword: flow injection, doxycycline hyclate, metol, green chemistry, aqueous medium.

DOI: $10.32434 / 0321-4095-2020-131-4-31-37$

\section{Introduction}

Doxycycline hyclate $\left(\mathrm{C}_{22} \mathrm{H}_{24} \mathrm{~N}_{2} \mathrm{O}_{8} \cdot \mathrm{HCl} \cdot 0.5\right.$ $\mathrm{C}_{2} \mathrm{H}_{5} \mathrm{OH} \cdot 0.5 \mathrm{H}_{2} \mathrm{O}$, molecular weight of $512.94 \mathrm{~g} \mathrm{~mol}^{-1}$, CAS number: 24390-14-5 [1]) is an extensive specter anti-bacterial tetracycline derivative with a broad range of activity against gram positive and gram negative organisms, including Spirochetes, Actinomyces sp., and Mycoplasma [2]. It is also a drug aimed at treating sexually transmitted diseases [3]. Doxycycline promotes other tetracyclines in the management of limited infections forasmuch as of its clearly absorption and its extended half-life, which permits less frequent dosage [4]. Doxycycline hyclate (DOX) is hydrochloride hemiethanol hemihydrate of doxycycline. The synonym for doxycycline hyclate is doxycycline hydrochloride. Doxycycline hyclate is much more dissolvable than doxycycline monohydrate, which is one of the chief purposes for it more frequent employment in pharmaceutical samples [2].

The drug is official in the British Pharmacopoeia (BP) [1], which describes HPLC methods for the determination of DOX either in raw material or in pharmaceutical formulations. Several methods have been reported for the determination of DOX in pharmaceutical dosage forms, including cloud point extraction [5], liquid chromatography [6], sequential injection chromatography [7], capillary electrophoresis [8], spectrophotometric methods [9] and flow-injection analysis (FIA) [10].

The chromatographic techniques [11-13] and spectrophotometric methods [9] are most widely used. Although the procedures are specific, most of the described methods are time-consuming and require multistage extraction procedures. On the other hand, the reported spectrophotometric methods suffer from one or the other disadvantages, such as poor sensitivity, the use of organic solvent that affected the environmental, the problems with extraction taking a lot of time, and the need for scrupulous control of experimental variables and special equipment.

The FIA methods reported in literature are continuous techniques which waste significant

(C) Assaf H. Tawfeeq, Bushra B. Qassim, 2020

A green method for assay of doxycycline hyclate using continuous flow injection/merging zones technique via coupling with azo metol in aqueous medium 
amounts of reagents making a noticeable pollution.

The aim of this work is to develop a simple green analytical method with a wide concentration range to be applicable for determination of DOX with high accuracy and precision.

\section{Experimental}

\section{Apparatus and manifold}

Measurements were carried out on an Optima VIS 9200 digital device with a single beam that records absorbance in a flow cell. The flow cell (quartz silica, $1 \mathrm{~cm}$ in length with internal volume of $100 \cdot \mu \mathrm{L}$ ) was inside the detection unit with the optical path of $1 \mathrm{~cm}$. The spectrophotometric device was coupled with Siemens (Kompensograph C1032) which gave the spectrophotometric response as a peak height expressed in millivolts $(\mathrm{mV})$.

A one-channel manifold flow injection system was used for spectrophotometric estimation of DOX. A power supply (Yaxun, 1501AD, China) was equipped with a peristaltic pump (Master flex C/L, USA). It used for pumping a carrier stream (distilled water) which passed through the injection valve (homemade; four-three-way injection valve that contained two loops made of Teflon). One of the loops carried DOX and the other carried azo metol; they were merged in a reaction coil. The linking tubes (used for linkage of the flow system parts) were made of flexible vinyl with the internal diameter of $0.22 \mathrm{~mm}$. The reaction coil was manufactured from glass with the internal diameter of $2 \mathrm{~mm}$. All parts of the flow injection system are shown in Fig. 1.

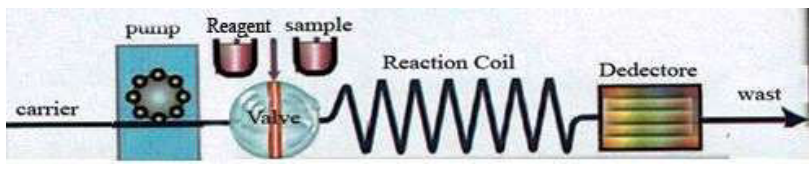

Fig. 1. Developed flow injection system

A carrier stream was distilled water that was joined with injected sample (DOX in $\mathrm{NaOH}$ solution) and merged with the reagent (azo metol). Then, it was mixed in a mixing coil. The length of the mixing coil was $50 \mathrm{~cm}$ and the flow rate of distilled water (a carrier) was $5 \mathrm{~mL} \mathrm{~min}{ }^{-1}$. The maximum absorption was found at the wavelength of $445 \mathrm{~nm}$.

\section{Chemicals and reagents}

All the chemical materials and reagents employed were of analytical class.

DOX stock solution (molecular weight of $512.94 \mathrm{~g} \mathrm{~mol}^{-1}$, Small Molecule Ltd, India) had a concentration of $1000 \mu \mathrm{g} \mathrm{mL} \mathrm{m}^{-1}=19.5 \cdot 10^{-4} \mathrm{M}$ ). To prepare this solution, $0.1 \mathrm{~g}$ of pure DOX was dissolved in distilled water and then brought up to $100 \mathrm{~mL}$ in a standard flask with distilled water. Diluted solutions of DOX were prepared by adequate diluting the stock standard solution with distilled water.

Metol (molecular weight of $344.38 \mathrm{~g} \mathrm{~mol}^{-1}$, Merck). Its concentration was $3 \cdot 10^{-3} \mathrm{M}$. To prepare this solution, $0.1 \mathrm{~g}$ of metol was dissolved in the smallest amount of water and then $2 \mathrm{~mL}$ of $0.5 \%$ $\mathrm{NaNO}_{2}$ and $1 \mathrm{~mL}$ of $0.1 \% \mathrm{HCl}$ were added in an ice bath $\left(0-5^{\circ} \mathrm{C}\right)$ for azotizing metol. After 5-10 min, the azotizing was completed. Then $2 \mathrm{~mL}$ of $2 \%$ sulphamic acid was added to the mixture to react with the residual of $\mathrm{NaNO}_{2} / \mathrm{HCl}$. Further, the volume was brought up to $100 \mathrm{~mL}$ in a standard flask. A further dilution of this solution yielded the solutions with desired concentrations [14].

$\mathrm{NaOH}$ (molecular weight of $40 \mathrm{~g} \mathrm{~mol}^{-1}, \mathrm{BDH}$ ). A $\mathrm{NaOH}$ solution (1\%) was prepared by dissolving $1 \mathrm{~g}$ of it in $100 \mathrm{~mL}$ of water. Diluted solutions of $\mathrm{NaOH}$ were prepared by adequate diluting the $1 \%$ solution with distilled water.

Pharmaceutical preparations of DOX $\left(1000 \mu \mathrm{g} \mathrm{mL} \mathrm{L}^{-1}\right)$

Pharmaceutical formulations were gained from trading sources. 20 capsules from four kinds of companies were assayed by the proposed procedures. The various providers from different companies were as follows:

(1) Tabocine (100 mg) Tabuk Pharmceutical Mfg.Co., Tabuk, Saudi Arabia,

(2) DuraDox (100 mg) Julphar, Gulf Pharmaceutical Industries, Ras Al Khaimah, United Arab Emirates,

(3) Doxycycline capsules (100 mg) actavis, New Delhi, India,

(4) Medomycin (100 mg) Medochemie Ltd., Cyprus.

Each capsule (20 in total) from each source was exactly weighed; and the weighed sample from the capsule from each source was taken and treated as a pure material in the procedure mentioned above. Then, the solutions were prepared with the concentration within the linearity of the calibration graph.

The recovery was assessed by determining the agreement between the measured concentration and the final known concentration of the sample. Each test was repeated three times. The limits of detection (LOD) and quantification (LOQ) were estimated according to ICH guidelines [15].

\section{Result and discussion}

Optimization of the FIA system conditions

Initial studies were directed towards the optimization of the experimental conditions for flow injection system-merging zones technique. A flow diagram (Fig. 2) shows that DOX is loaded in the first loop and azo metol with $\mathrm{NaOH}$ solution is loaded in the second loop. Then, both DOX and azo metol- 


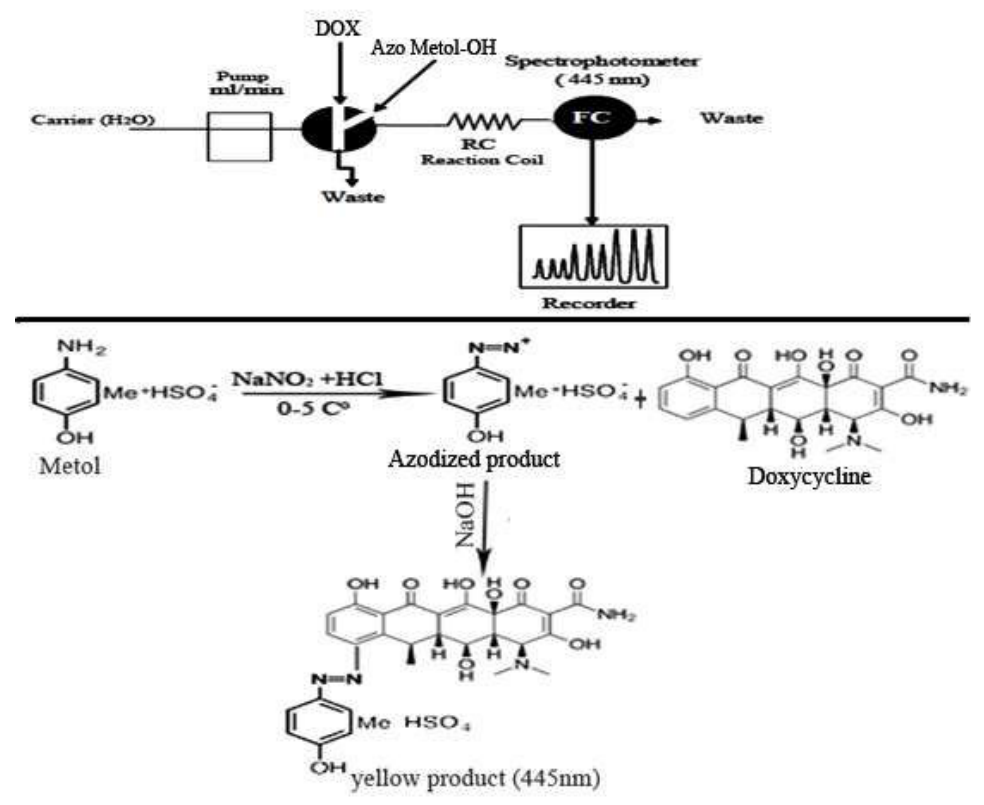

Fig. 2. Flow diagram and reaction equation

$\mathrm{OH}^{-}$are merged in the reaction coil by carrier stream of distilled water. The reaction equation is shown in Fig. 2.

\section{Effect of chemical and physical variables}

Effect of chemical variables (concentration of reagent) and physical parameters (flow rate, length of reaction coil and the injected volumes of reagent and sample) were studied.

The effect of concentration of the reagent (azo metol) was studied by injecting different concentrations $\left(0.5 \cdot 10^{-4}-3 \cdot 10^{-4} \mathrm{M}\right)$. The results indicate (Fig. 3) that the concentration of $2 \cdot 10^{-4} \mathrm{M}$ give the highest value of absorbance expressed as a peak height (expressed in $\mathrm{mV}$ ) with high repeatability. This means a perfect reaction between DOX and azo metol. A higher concentration of azo metol results in a reverse reaction (according to the Le Chatelier principle) and inhibits the favorable response.

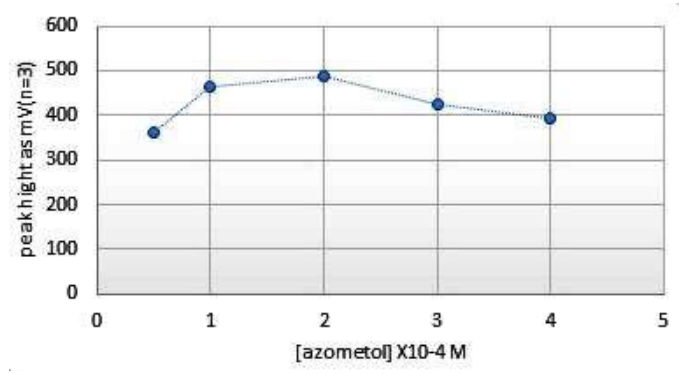

Fig. 3. Influence of the concentration of azo metol $\left(100 \mu \mathrm{g} \mathrm{mL} \mathrm{L}^{-1}\right.$ DOX and $\left.0.7 \mathrm{M} \mathrm{NaOH}\right)$ on the peak height in flow injection system
Effect of flow rate and sample throughput

All available flow rates were inspected for the system under consideration (Fig. 4). As can be seen, the «best» flow rate was $5 \mathrm{~mL} \mathrm{~min}{ }^{-1}$, which was enough to ensure a complete reaction between DOX and azo metol. A higher flow rate (greater than $5 \mathrm{~mL} \mathrm{~min}{ }^{-1}$ ) led to an incomplete reaction and a lower flow rate resulted in a low samples throughput.

The sample throughput at the flow rate of $5 \mathrm{~mL} \mathrm{~min}{ }^{-1}$ was about 120 samples per hour, the sampling rate was calculated depending on time required for loading the drug and the reagent to loops of the four three-way valve plus the time required for appearance of a maximum peak height (this time was found to be $15 \mathrm{~s}$ ). In addition, $15 \mathrm{~s}$ were required for loading reagent and drug. Therefore, the sampling rate was 120 samples per hour.

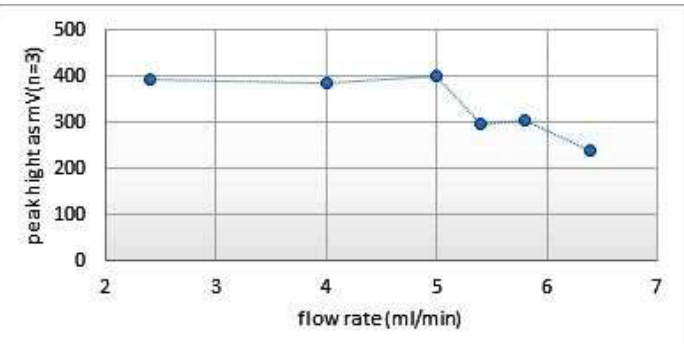

Fig. 4. Effect of flow rate $\left(75 \mu \mathrm{g} \mathrm{mL} \mathrm{L}^{-1} \mathrm{DOX}\right)$

\section{Analytical calibration curve}

A series of solutions with different DOX concentrations (from 0.5 to $150 \mu \mathrm{g} \mathrm{mL} \mathrm{mL}^{-1}$ ) was prepared and injected into FIA system together with azo metol, in order to establish the optimum range 


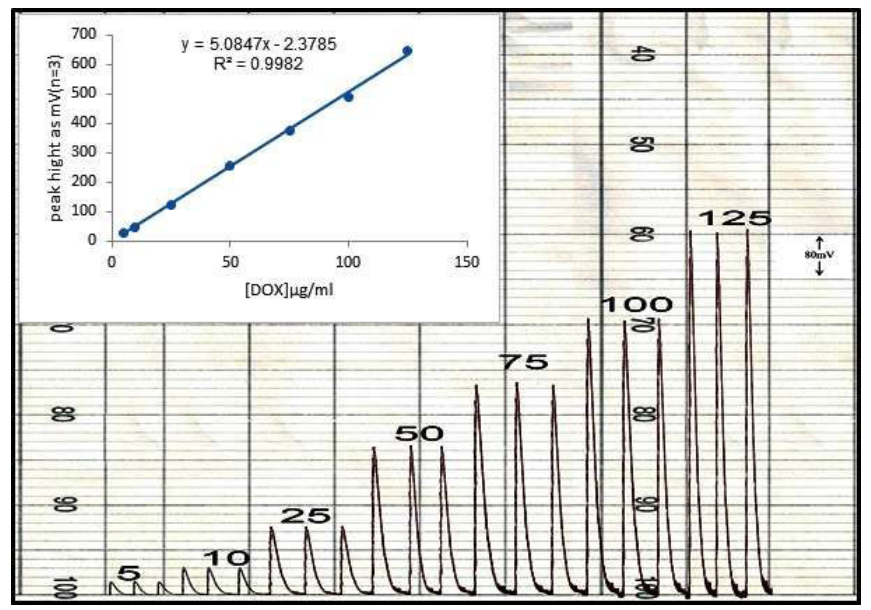

Fig. 5. Dynamic range for reaction between azo metol and DOX and calibration curve

Calibration table for the system $\mathrm{DOX}-$ azo metol $-\mathrm{OH}^{-}$

\begin{tabular}{|c|c|c|c|c|c|c|c|}
\hline \multirow{2}{*}{$\begin{array}{c}\begin{array}{c}\text { DOX } \\
\text { concentration } \\
\left(\mu \mathrm{g} \mathrm{mL}^{-1}\right)\end{array} \\
5 \\
\end{array}$} & \multicolumn{3}{|c|}{ Peak high (mV) } & \multirow{2}{*}{$\begin{array}{c}\text { Arithmetic } \\
\text { mean }(\mathrm{mV})\end{array}$} & \multirow{2}{*}{$\begin{array}{c}\begin{array}{r}\text { Standard } \\
\text { deviation }\end{array} \\
1.73\end{array}$} & \multirow{2}{*}{$\begin{array}{l}\text { Root mean standard } \\
\text { deviation, RSD }(\%)\end{array}$} & \multirow{2}{*}{$\frac{\mathrm{y} \pm \mathrm{t}(\mathrm{SD} / \sqrt{\mathrm{n}})}{27.2 \pm 2.4}$} \\
\hline & 26.2 & 26.2 & 29.2 & & & & \\
\hline 10 & 46.0 & 47.0 & 51.0 & 48.0 & 2.65 & 5.51 & $48 \pm 3.6$ \\
\hline 25 & 123.0 & 123.6 & 122.8 & 123.1 & 0.42 & 0.34 & $123.1 \pm 0.6$ \\
\hline 50 & 255.0 & 255.0 & 257.0 & 255.7 & 1.15 & 0.45 & $255.7 \pm 1.6$ \\
\hline 75 & 378.0 & 376.0 & 374.0 & 376.0 & 2.00 & 0.53 & $376 \pm 2.7$ \\
\hline 100 & 488.5 & 488.0 & 487.5 & 488.0 & 0.50 & 0.10 & $488 \pm 0.7$ \\
\hline 125 & 646.0 & 646.0 & 652.0 & 648.0 & 3.46 & 0.53 & $648 \pm 4.7$ \\
\hline
\end{tabular}

of DOX concentration which can be applicable for this method. The results obtained showed that the «best» concentration range extended from $5 \mu \mathrm{g} \mathrm{mL} \mathrm{m}^{-1}$ to $125 \mu \mathrm{g} \mathrm{mL} \mathrm{m}^{-1}$ as shown in Fig. 5 and Table 1 . [16]

Analysis of variation of linear equation (ANOVA)

First, we calculated the sum of squares of the difference between the values of $y_{i}$ (response) and $\hat{y}_{i}$ (estimated response) to obtain $\sum\left(y_{i}-\hat{y}_{i}\right)^{2}$ for $(n-2)$ degrees of freedom and get the sum of squares $\left(\mathrm{S}_{\mathrm{o}}\right)^{2}$. Then, we calculated the sum of squares of the variance between the values of $\hat{y}_{i}$ and average value (due to regression) to obtain $\sum\left(\hat{y}_{i}-\bar{y}\right)^{2}$ for $(n-1)$ degrees of freedom and get the sum of squares (SS) ${ }^{2}$. Finally, we found the mean of squares $\left(\mathrm{MS}_{0}\right)$ and
$\left(\mathrm{MS}_{1}\right)$. When dividing the $\left(\mathrm{MS}_{\mathrm{o}}\right)$ by $\left(\mathrm{MS}_{1}\right)$, the value (F) was got as showed in Table 2. We determined that $F_{\text {crit }}(4.7)<<F(10)$, hence it could be concluded that there was an important relation between the concentration of DOX and the signal got.

\section{Methods validation}

The analytical characteristics, such as correlation coefficient, detection limit, linear range and relative standard deviation [17], were estimated (Table 3). A calibration curve was constructed (the inset in Fig. 5) for a set of DOX standard solutions. Statistical assessment of regression line (standard deviation for residuals $(\mathrm{Sy} / \mathrm{x})$, intercept $\left(\mathrm{S}_{\mathrm{a}}\right)$ and slope $\left.\left(\mathrm{S}_{\mathrm{b}}\right)\right)$ under the $95 \%$ confidence limits for $(\mathrm{n}-2)$ degrees of freedom are summarized in Table 3. The

Table 2

Analysis of variation

\begin{tabular}{l|c|c|c|c|c}
\hline \multicolumn{1}{c|}{ Source of variation } & Sum of squares (SS) & Degrees of freedom & Mean of squares (MS) & $\mathrm{F}\left(\mathrm{S}_{1}{ }^{2} / \mathrm{S}_{2}{ }^{2}\right)$ & \multirow{2}{*}{$\mathrm{F}_{\text {crit }}$} \\
\hline Between groups (factor) & 276185.7 & 1 & 276185.7 & & \multirow{2}{*}{10} \\
\cline { 1 - 4 } Within groups (error) & 330786.7 & 12 & 27565.6 & & \multirow{2}{*}{4.7} \\
\hline Total & 606972.3 & 13 & & \\
\hline
\end{tabular}


Table 3

Analytical characteristics of calibration curve for azo metol-DOX system

\begin{tabular}{|c|c|}
\hline Parameters & Values \\
\hline$\lambda_{\max }(\mathrm{nm})$ & 445 \\
\hline Regression equation & $y=5.1 x-2.4$ \\
\hline Dynamic range $\left(\mu \mathrm{g} \mathrm{mL}^{-1}\right)$ & $5-125$ \\
\hline Average recovery $(\%)$ & 98.9 \\
\hline Error $(\mathrm{E} \%)$ & 1.1 \\
\hline RSD (\%) & 0.8 \\
\hline Slope, $\mathrm{b}\left(\mathrm{mL} \mu \mathrm{g}^{-1}\right)$ & 5.1 \\
\hline Intercept, a & 2.4 \\
\hline Correlation coefficient $\left(\mathrm{R}^{2}\right)$ & 0.9982 \\
\hline Standard deviation of slope $\left(\mathrm{S}_{\mathrm{b}}\right)$ & 0.005 \\
\hline Standard deviation of intercept $\left(\mathrm{S}_{\mathrm{a}}\right)$ & 0.005 \\
\hline $\mathrm{LOD}\left(\mu \mathrm{g} \mathrm{mL}^{-1}\right)$ & 0.2 \\
\hline $\mathrm{LOQ}\left(\mu \mathrm{g} \mathrm{mL}^{-1}\right)$ & 1 \\
\hline Sample throughput (samples per hour) & 120 \\
\hline
\end{tabular}

results showed the high repeatability and reproducibility of the proposed flow injection analysis. The flow injection/merging zones analysis was easy, accurate and rapid (sample throughput of 120 samples per hour) and a relatively wide linear scale of calibration curves was observed.

Study of interferences from impurities

In order to examine the selectivity of the developed method, the interference of possible impurities, such as starch, sucrose, fructose, glucose and sodium citrate, was studied.

Samples of pure DOX spiked with a half, equal and twofold excess concentrations of the selected impurities were analyzed (Table 4). The obtained recovery values demonstrated that there were no interferences during the determination of DOX using proposed flow injection methods unless the twofold excess concentrations.

\section{Assessment of the suggested method}

To assess the success and efficiency of the proposed method, four types of capsules containing DOX coming from different origins (Kingdom of Saudi Arabia, United Arab Emirates, India and Cyprus) were analyzed by means of the developed technique.

The capsules were prepared according to the above-mentioned procedure. After preparing the solution of these capsules, the proposed flow injection-merging zones technique method was used to estimate the DOX content in capsules and the results are listed in Table 5. The results obtained were compared with those obtained by applying standard (British pharmacopoeia) HPLC method. The calculated concentrations were practically equal to the theoretical ones. The statistical calculations
Table 4

Interferences from impurities on the determination of DOX $\left(50 \mu g \mathrm{~mL}^{-1}\right)$

\begin{tabular}{l|c|c|c|c}
\hline Impurity & $\begin{array}{c}\text { Concentration } \\
\left(\mu \mathrm{g} \mathrm{mL}^{-1}\right)\end{array}$ & $\begin{array}{c}\text { Peak } \\
\text { height }\end{array}$ & $\mathrm{mV}$ & $\begin{array}{c}\text { Recovery } \\
(\%)\end{array}$ \\
\hline \multirow{4}{*}{ Starch } & 50 & 30.25 & 484 & 95.65 \\
\cline { 2 - 5 } & 100 & 30.25 & 484 & 95.65 \\
\cline { 2 - 5 } & 200 & 25 & 400 & 79.13 \\
\hline \multirow{3}{*}{ Sucrose } & 50 & 30.5 & 488 & 96.44 \\
\cline { 2 - 5 } & 100 & 27.5 & 440 & 97.00 \\
\hline \multirow{3}{*}{ Glucose } & 200 & 26.75 & 428 & 84.64 \\
\cline { 2 - 5 } & 50 & 30 & 480 & 94.86 \\
\cline { 2 - 5 } & 100 & 30 & 480 & 94.86 \\
\hline \multirow{3}{*}{ Fructose } & 200 & 29.25 & 468 & 92.50 \\
\cline { 2 - 5 } & 50 & 30.25 & 484 & 95.65 \\
\hline \multirow{2}{*}{$\begin{array}{l}\text { Sodium } \\
\text { citrate }\end{array}$} & 200 & 30.25 & 480 & 94.86 \\
\cline { 2 - 5 } & 50 & 30.75 & 492 & 95.65 \\
\hline & 100 & 30.5 & 488 & 97.22 \\
\hline
\end{tabular}

showed the following results with respect to the Student's (t-) and F-tests [16]:

$$
\mathrm{t}_{\text {calculated }}=2.21<\mathrm{t}_{\text {crit. }}=2.23
$$

(where $\mathrm{n} 1=8$ and $\mathrm{n} 2=4$, hence $\mathrm{n} 1+\mathrm{n} 2-2=10$ );

$$
\mathrm{F}_{\text {calculated }}=2.92<\mathrm{F}_{\text {crit. }}=8.88
$$

(where $n 1-1=7$ and $n 2-1=3$ at the $95 \%$ confidence level).

\section{Conclusions}

A few FIA methods were described in literature for determination of DOX and most these methods were either not precise enough or complicated and costly. The homemade continuous flow injectionmerging zones analytical procedure can be successfully used for the spectrophotometric determination of DOX in pharmaceutical formulations. Comparison between the developed technique and the flow injection methods reported previously showed that the proposed method is characterized by a wider calibration range (from

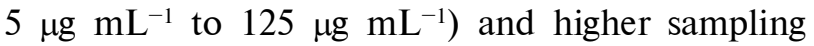
rate. Moreover, it involves the use of an aqueous medium and do not require any sample pretreatment or transmutation. The main advantages of the method are its huge workings range, suitable sensitivity and its suitability for routine examination in pharmaceutical control laboratories. The procedure ensures the throughput of 120 samples per hour.

\section{REFERENCES}

1. British pharmacopoeia. - London: Stationary Office, 
Table 5

Comparison between the proposed and official methods

\begin{tabular}{l|c|c|c|c|c|c|c}
\hline & \multicolumn{5}{|c|}{} & $\begin{array}{c}\text { British } \\
\text { pharmacopo } \\
\text { ia method }\end{array}$ \\
\cline { 2 - 8 } & $\begin{array}{c}\text { Dosage form } \\
\text { concentration } \\
(\mu \mathrm{g} \mathrm{mL})\end{array}$ & $\begin{array}{c}\text { Added } \\
\text { concentration } \\
\left(\mu \mathrm{g} \mathrm{mL}^{-1}\right)\end{array}$ & $\begin{array}{c}\text { Final taken } \\
\text { concentration } \\
\left(\mu \mathrm{gL}^{-1}\right)\end{array}$ & $\begin{array}{c}\text { Found } \\
\text { concentration } \\
\left(\mu \mathrm{mL}^{-1}\right)\end{array}$ & $\begin{array}{c}\text { Recovery } \\
(\%)\end{array}$ & $\begin{array}{c}\text { Relative } \\
\text { standard } \\
\text { deviation }(\%)\end{array}$ & $\begin{array}{c}\text { Recovery } \\
(\%)\end{array}$ \\
\hline $\begin{array}{l}\text { Tabucen (100 mg) } \\
\text { (Kingdom of Saudi }\end{array}$ & 25 & 25 & 50 & 50 & 100 & 1.05 & 95 \\
$\begin{array}{l}\text { Arabia) } \\
\begin{array}{l}\text { DuraDox (100 mg) } \\
\text { (United Arab } \\
\text { Emirates) }\end{array}\end{array}$ & 25 & 25 & 50 & 48.5 & 97 & 0.82 & 96 \\
\hline $\begin{array}{l}\text { DOX (100 mg) } \\
\text { (India) }\end{array}$ & 25 & 25 & 50 & 48.2 & 96.4 & 0.86 & 97 \\
\hline $\begin{array}{l}\text { Medomycin } \\
(100 \mathrm{mg}) \text { (Cyprus) }\end{array}$ & 25 & 25 & 50 & 47.6 & 95.2 & 0.01 & 98 \\
\hline
\end{tabular}

2001, pp. 526-527.

2. UV assay method for the determination of Doxycycline hyclate in bulk and pharmaceutical formulation / Sreeram V., Nagendrakumar A.V.D., Srinivasa Rao Karumuri, Madhu M. // Chem. Sci. Trans. - 2015. - Vol.4. - No. 1. - P.69-74.

3. Kumar A., Nanda S., Chomwal R. Spectrophotometeric methods for determination of doxycycline in Tablet Formulation // Int. J. PharmTech. Res. - 2010. - Vol.2. - No. 1. - P.599-602.

4. Al-Kalissy R.S., Mohammed A.K. Spectrophotometric method for the determination of tetracycline and doxycycline by oxidizing coupling reaction with 4-aminoantipyrine // Ibn AlHaitham J. Pure Appl. Sci. - 2015. - Vol.28. - No. 3. - P.154-168.

5. Zuhair A.A.K., Rana A.R. Visible spectrophotometric analysis for the mutual determination of doxycycline hydrochloride and iron in real samples after cloud point extraction // Int. J. Chem. Sci. - 2016. - Vol.14. - No. 2. - P.955-977.

6. Kogawa A.C., Salgado H.R.N. Quantification of doxycycline hyclate in tablets by HPLC-UV method // J. Chromatogr. Sci. - 2013. - Vol.51. - P.919-925.

7. Sequential injection chromatographic determination of ambroxol hydrochloride and doxycycline in pharmaceutical preparations / Satinsky D., Dos Santos L.M.L., Sklenarova H., Solich P., Montenegro M.C.B.S.M., Araujo A.N. // Talanta. 2005. - Vol.68. - P.214-218.

8. Jang M.G., Jang M.D., Park J.H. Doxycycline as a new chiral selector in capillary electrophoresis // J. Chromatogr. A. 2017. - Vol.1508. - P.176-181.

9. Ramesh P.J., Basavaiah K., Rajendraprasad N. Sensitive and selective spectrophotometric assay of doxycycline hyclate in pharmaceuticals using Folin-Ciocalteu reagent // Acta Pharm. (Zagreb, Croatia). - 2010. - Vol.60. - P.445-454.

10. Al-Abachi M.Q., Al-Nedawi Z.A. Batch and flow injection spectrophotometric determination of doxycycline hyclate in pharmaceutical preparations // J. Al-Nahrain Univ. - 2015. Vol.18. - No. 3. - P.24-32.
11. RP-HPLC method development and validation of doxycycline in bulk and tablet formulation / Jeyabaskaran M., Rambabu C., Sree Janardhanan V., Rajinikanth V., Pranitha T., Dhanalakshmi B. // Int. J. Pharm. Anal. Res. - 2014. - Vol.3. No. 4. - P.397-404.

12. A rapid and reliable determination of doxycycline hyclate by HPLC with UV detection in pharmaceutical samples / Mitic S.S., Miletic G.Z., Kostic D.A., Naskovic-Dokic D.C., Arsic B.B., Rasic I.D. // J. Serb. Chem. Soc. - 2008. - Vol.73. - No. 6. P.665-671.

13. Mileva $R$. Determination of free doxycycline concentrations in the plasma and milk of sheep and in the plasma of rabbits by using the HPLC method // Maced. Vet. Rev. 2019. - Vol.42. - No. 2. - P.123-130.

14. Development of spectrophotometric method for determination of ceftazidime with the Bratton-Marshall reagent in pharmaceutical preparation / Dung N.T., Dao D.T., Hoat G.D., Son N.A. // J. Sci. Technol. - 2017. - Vol.55. - No. 2. P.220-228.

15. ICH Harmonised tripartite guideline, validation of analytical procedures: text and methodology Q2(R1). - 2005. P.11-13. Available from: https://www.ich.org/page/qualityguidelines.

16. Miller J.C., Miller J.C. Statistics for analytical chemistry, 6th Edition. - Pearson Education Limited, 2010. - Chapter 3. P.43-59.

17. Flow-injection spectrophotometric system for captopril determination in pharmaceuticals / Suarez W.T., Madi A.A., de-Figueiredo-Filho L.S.C., Fatibello-Filho O. // J. Braz. Chem. Soc. - 2007. - Vol.18. - No. 6. - P.1215-1219.

Received 01.04.2020 


\section{ЕКОЛОГІЧНО ПРИЙНЯТНИЙ МЕТОД АНАЛІЗУ ДОКСИЦИКЛІН ГІКЛАТУ 3 ВИКОРИСТАННЯМ МЕТОДИКИ ЗОН БЕЗПЕРЕРВНОЇ ПРОТОЧНОЇ ІН'ЕКЦЇ̈/ЗОН ЗЛИТТЯ 3 АЗОМЕТОЛОМ У ВОДНОМУ СЕРЕДОВИЩІ \\ Ассаф Х. Тавфік, Бушра Б. Кассім}

Розроблено просту, автоматизовану, чутливу і екологічно прийнятну методику зон безперервної проточної ін'єкції/ зон злиття для визначення доксициклін гіклату в сировині $i$ фармацевтичних складах. Уданому методі використовується реакція азометолу з доксициклін гіклатом з утворенням розчинного комплексу із жовтим забарвленням ( $\lambda_{\max }=445$ нм). Розроблена методика є простою і дешевою, вона забезпечує використання водного середовища, яке є нетоксичним $і$ не забруднює навколишнє середовище. Методика є чутливою і точною $з$ межею визначення менше, ніж 0,3 мкг/мл, відносне стандартне відхилення менше, ніж 1.5\%, і уловлювання близько 98\%. Досліджсені різноманітні хімічні і фізичні умови, що впливають на реакцію. Аналітична калібрувальна залежність була лінійною в межах концентрацій від 5 до 125 мкг/мл. Пропускна здатність методики приблизно 120 зразків за годину. Запропонована методика може бути успішно використана для визначення доксициклін гіклату. Результати визначень були задовільними у порівнянні з отриманими стандартними методами, внесеними до британської фармакопеї: не спостерігалося суттєвих відмінностей між результатами, отриманими за допомогою обох методик за точністю на 95\%-вому довірчому рівні.

Ключові слова: проточна ін'єкція, доксициклін гіклат, метол, «зелена» хімія, водне середовище.

\section{A GREEN METHOD FOR ASSAY OF DOXYCYCLINE HYCLATE USING CONTINUOUS FLOW INJECTION/ MERGING ZONES TECHNIQUE VIA COUPLING WITH AZO METOL IN AQUEOUS MEDIUM}

\section{Assaf H. Tawfeeq *, Bushra B. Qassim \\ University of Baghdad, Baghdad, Iraq \\ * e-mail: assaf.hameed@gmail.com}

A simple, automated, sensitive and environmentally friendly flow-injection/merging zones technique was developed for the determination of doxycycline hyclate in raw materials and pharmaceutical formulations. This method involves the reaction of azo metol with doxycycline hyclate to produce a yellow dissolved complex with a $\lambda_{\max }=445 \mathrm{~nm}$. The developed technique is simply and low-cost, it provides the use of an aqueous medium that is nontoxic and causes no pollution, thereby belonging to green chemistry. The method is sensitive, precise and accurate; the limit of detection is less than $0.3 \mu \mathrm{g} \mathrm{mL} L^{-1}$, the relative standard deviation is less than $1.5 \%$ and the recovery is about $98 \%$. Various chemical and physical conditions that affected the reaction have been studied. An analytical calibration curve was linear within the concentration range of 5 to $125 \mu \mathrm{g} \mathrm{mL} L^{-1}$. The sample throughput is about 120 samples per hour. The proposed procedure can be successfully applied to estimate the content of doxycycline hyclate. The results of determination are satisfactory as compared with those given by a reference method of British Pharmacopeia: there is no significant difference between the results obtained by both methods regarding accuracy and precision at the $95 \%$ confidence level.

Keyword: flow injection; doxycycline hyclate; metol; green chemistry; aqueous medium.

\section{REFERENCES}

1. British pharmacopoeia. The Stationary Office, London, 2001, pp. 526-527.
2. Sreeram V., Nagendrakumar A.V.D., Srinivasa Rao Karumuri, Madhu M. UV assay method for the determination of Doxycycline hyclate in bulk and pharmaceutical formulation. Chemical Science Transactions, 2015, vol. 4, no. 1, pp. 69-74.

3. Kumar A., Nanda S., Chomwal R. Spectrophotometeric methods for determination of doxycycline in Tablet Formulation. International Journal of Pharm Tech Research, 2010, vol. 2, no. 1, pp. 599-602.

4. Al-Kalissy R.S., Mohammed A.K. Spectrophotometric method for the determination of tetracycline and doxycycline by oxidizing coupling reaction with 4-aminoantipyrine. Ibn AlHaitham Journal for Pure \& Applied Science, 2015, vol. 28, no. 3, pp. 154-168.

5. Zuhair A.A.K., Rana A.R. Visible spectrophotometric analysis for the mutual determination of doxycycline hydrochloride and iron in real samples after cloud point extraction. International Journal of Chemical Science, 2016, vol. 14, no. 2, pp. 955-977.

6. Kogawa A.C., Salgado H.R.N. Quantification of doxycycline hyclate in tablets by HPLC-UV method. Journal of Chromatographic Science, 2013, vol. 51, pp. 919-925.

7. Satinsky D., Dos Santos L.M.L., Sklenarova H., Solich P., Montenegro M.C.B.S.M., Araujo A.N. Sequential injection chromatographic determination of ambroxol hydrochloride and doxycycline in pharmaceutical preparations. Talanta, 2005, vol. 68 , pp. 214-218.

8. Jang M.G., Jang M.D., Park J.H. Doxycycline as a new chiral selector in capillary electrophoresis. Journal of Chromatography A, 2017, vol. 1508, pp. 176-181.

9. Ramesh P.J., Basavaiah K., Rajendraprasad N. Sensitive and selective spectrophotometric assay of doxycycline hyclate in pharmaceuticals using Folin-Ciocalteu reagent. Acta Pharmaceutica (Zagreb, Croatia), 2010, vol. 60, pp. 445-454.

10. Al-Abachi M.Q., Al-Nedawi Z.A. Batch and flow injection spectrophotometric determination of doxycycline hyclate in pharmaceutical preparations. Journal of Al-Nahrain University, 2015 , vol. 18 , no. 3 , pp. 24-32.

11. Jeyabaskaran M., Rambabu C., Sree Janardhanan V., Rajinikanth V., Pranitha T., Dhanalakshmi B. RP-HPLC method development and validation of doxycycline in bulk and tablet formulation. International Journal of Pharmacy and Analytical Research, 2014, vol. 3, no. 4, pp. 397-404.

12. Mitic S.S., Miletic G.Z., Kostic D.A., Naskovic-Dokic D.C., Arsic B.B., Rasic I.D. A rapid and reliable determination of doxycycline hyclate by HPLC with UV detection in pharmaceutical samples. Journal of the Serbian Chemical Society, 2008, vol. 73, no. 6, pp. 665-671.

13. Mileva R. Determination of free doxycycline concentrations in the plasma and milk of sheep and in the plasma of rabbits by using the HPLC method. Macedonian Veterinary Review, 2019, vol. 42, no. 2, pp. 123-130.

14. Dung N.T., Dao D.T., Hoat G.D., Son N.A. Development of spectrophotometric method for determination of ceftazidime with the Bratton-Marshall reagent in pharmaceutical preparation. Journal of Science and Technology, 2017 , vol. 55, no. 2 , pp. 220-228.

15. ICH Harmonised tripartite guideline, validation of analytical procedures: text and methodology Q2(R1), 2005, pp. 1113. Available from: https://www.ich.org/page/quality-guidelines.

16. Miller J.C., Miller J.C., Statistics for analytical chemistry, 6th Edition. Pearson Education Limited, England, 2010, Chapter 3, pp. 43-59.

17. Suarez W.T., Madi A.A., de-Figueiredo-Filho L.S.C., Fatibello-Filho O. Flow-injection spectrophotometric system for captopril determination in pharmaceuticals. Journal of the Brazilian Chemical Society, 2007, vol. 18, no. 6, pp. 1215-1219. 